\title{
Port Environmental Risk Assessment, Case Study: Port of Perama
}

\author{
D. Lagoudaki \\ Dept. of Industrial Design and \\ Production Engineering University of \\ West Attica \\ Athens, Greece
}

\author{
N. Nikitakos \\ Dpt. of Shipping Trade \& Transport, \\ University of Aegean \\ Greece
}

\author{
D. Papachristos \\ Dept. Industrial Engineering and \\ Production \\ University of West Attica \\ Greece
}

\begin{abstract}
Much of the world prosperity today has been produced or facilitated by seaports and their associated activities. In recent decades, ports have grown alongside the emerging global economy and global hubs for large-scale effective trade and shipping. Traditionally, port authorities were more concerned about the impact of the environment on their own activities, rather than vice versa. However, environmental issues have widened in scope and public awareness has increased, leading to the establishment of environmental organizations and the establishment of rigorous environmental regulations to address the problem. The Municipality of Perama is located in the south-western part of the Attica Basin and belongs to the Regional Unity of Piraeus and is a city with a great connection to the port and shipping. In a questionnaire shared with workers and residents in the city, the majority of respondents believe that the environment of the city of Perama is in poor condition but can be saved with a lot of effort. Regarding the responsibility for environmental pollution in the municipality of Perama, most of the responses were concentrated on the industries operating in the area as well as on the operation of port facilities, and they consider that it is primarily the responsibility of the government to create a healthy and safe environment. Finally, from the analysis of the measurements made in the city, we observe that Perama is a particularly vulnerable area in terms of both marine and air pollution, with concentrations of some heavy metals and particulate matter exceeding the statutory limits.
\end{abstract}

\section{Keywords}

Port, Marine pollution, Shipbuilding Zone, Air polution

\section{INTRODUCTION}

The ports, mainly due to the development of the Asian countries and globalization, have seen prime growth over the last decades. In strategically located points on the ocean, sea, river and lake coasts, in order to obtain the best possible access to land and floating waters, to satisfy existing commercial demand and to provide shelter from the wind and waves on ships, ports can either be physical units or artificial structures that provide for cargo and passengers to be loaded and unloaded. However, ports, and in particular industrial ports, are heavy carbon dioxide producers (CO2), gaseous particles (PM10) and other emissions and noise. (Harry Geerlings, 2017) Traditionally, port authorities were more concerned about the impact of the environment on their own activities than on the contrary. In the 1970s and 1980s, even with a growing awareness of the environmental check, compliance with legislation remained the main guide for port authorities to consider launching any kind of environmental management program.

\section{ENVIRONMENTAL POLLUTION FROM PORT FACILITIES}

2.1 The increase in international trade has led to a corresponding rapid increase in the volume of goods transported by sea. Despite the enormous growth in maritime shipping, most pollution prevention efforts at local, state and federal levels have focused on other sources of pollution, while the environmental impacts of ports have increased. The result is that the most major ports are heavy pollutants, releasing to a large extent amounts of harmful atmospheric and aquatic pollutants that are unmanageable, causing noise and light pollution that disrupt the surrounding communities and damage marine habitats. Through regular surveys, ESPO and EcoPorts have been following the top environmental priorities of the European port sector since 1996. The following table shows the changes in the environmental priorities of ports from 1996 to 2017. Many of these reflect the prevailing political driving forces. Priority issues are changing over time, but some elements retain their importance for the sector.

Table 1: Top 10 environmental priorities of EU ports [1]

\begin{tabular}{|c|c|c|c|c|c|c|}
\hline & 1996 & 2004 & 2009 & 2013 & 2016 & 2017 \\
\hline 1 & $\begin{array}{c}\text { Port } \\
\text { develo } \\
\text { pment } \\
\text { (water) }\end{array}$ & $\begin{array}{c}\text { Garba } \\
\text { ge/ } \\
\text { Port } \\
\text { waste }\end{array}$ & Noise & $\begin{array}{c}\text { Air } \\
\text { quality }\end{array}$ & $\begin{array}{c}\text { Air } \\
\text { quality }\end{array}$ & $\begin{array}{c}\text { Air } \\
\text { quality }\end{array}$ \\
\hline 2 & $\begin{array}{l}\text { Water } \\
\text { quality }\end{array}$ & $\begin{array}{c}\text { Dredgi } \\
\text { ng: } \\
\text { operati } \\
\text { ons }\end{array}$ & $\begin{array}{c}\text { Air } \\
\text { quality }\end{array}$ & $\begin{array}{c}\text { Garba } \\
\text { ge/ } \\
\text { Port } \\
\text { waste }\end{array}$ & $\begin{array}{c}\text { Energ } \\
\text { y } \\
\text { consu } \\
\text { mption }\end{array}$ & $\begin{array}{c}\text { Energ } \\
y \\
\text { consu } \\
\text { mption }\end{array}$ \\
\hline 3 & $\begin{array}{c}\text { Dredgi } \\
\text { ng } \\
\text { disposa } \\
1\end{array}$ & $\begin{array}{c}\text { Dredgi } \\
\text { ng } \\
\text { dispos } \\
\text { al }\end{array}$ & $\begin{array}{c}\text { Garba } \\
\text { ge/ } \\
\text { Port } \\
\text { waste }\end{array}$ & $\begin{array}{c}\text { Energ } \\
\text { y } \\
\text { consu } \\
\text { mption }\end{array}$ & Noise & Noise \\
\hline 4 & $\begin{array}{c}\text { Dredgi } \\
\text { ng: } \\
\text { operati } \\
\text { ons }\end{array}$ & Dust & $\begin{array}{c}\text { Dredgi } \\
\text { ng: } \\
\text { operati } \\
\text { ons }\end{array}$ & Noise & $\begin{array}{c}\text { Relati } \\
\text { onship } \\
\text { with } \\
\text { local } \\
\text { comm } \\
\text { unity }\end{array}$ & $\begin{array}{l}\text { Water } \\
\text { quality }\end{array}$ \\
\hline 5 & Dust & Noise & $\begin{array}{c}\text { Dredgi } \\
\text { ng } \\
\text { dispos } \\
\text { al }\end{array}$ & $\begin{array}{c}\text { Ship } \\
\text { waste }\end{array}$ & $\begin{array}{c}\text { Garba } \\
\text { ge/ } \\
\text { Port } \\
\text { waste }\end{array}$ & $\begin{array}{l}\text { Dredgi } \\
\text { ng: } \\
\text { operati } \\
\text { ons }\end{array}$ \\
\hline 6 & $\begin{array}{c}\text { Port } \\
\text { develo }\end{array}$ & Air & $\begin{array}{l}\text { Relati } \\
\text { onship }\end{array}$ & $\begin{array}{l}\text { Relati } \\
\text { onship }\end{array}$ & Ship & $\begin{array}{c}\text { Garba } \\
\text { ge/ }\end{array}$ \\
\hline
\end{tabular}




\begin{tabular}{|c|c|c|c|c|c|c|}
\hline & $\begin{array}{l}\text { pment } \\
\text { (land } \\
\text { related) }\end{array}$ & quality & $\begin{array}{l}\text { with } \\
\text { local } \\
\text { comm } \\
\text { unity }\end{array}$ & $\begin{array}{l}\text { with } \\
\text { local } \\
\text { comm } \\
\text { unity }\end{array}$ & waste & $\begin{array}{c}\text { Port } \\
\text { waste }\end{array}$ \\
\hline 7 & $\begin{array}{l}\text { Conta } \\
\text { minate } \\
\text { d land }\end{array}$ & $\begin{array}{c}\text { Hazar } \\
\text { dous } \\
\text { cargo }\end{array}$ & $\begin{array}{c}\text { Energ } \\
\text { y } \\
\text { consu } \\
\text { mption }\end{array}$ & $\begin{array}{c}\text { Dredgi } \\
\text { ng: } \\
\text { operati } \\
\text { ons }\end{array}$ & $\begin{array}{c}\text { Port } \\
\text { develo } \\
\text { pment } \\
\text { (land } \\
\text { related } \\
\text { ) }\end{array}$ & $\begin{array}{c}\text { Port } \\
\text { develo } \\
\text { pment } \\
\text { (land } \\
\text { related } \\
\text { ) }\end{array}$ \\
\hline 8 & $\begin{array}{l}\text { Habitat } \\
\text { loss/ } \\
\text { degrad } \\
\text { ation }\end{array}$ & $\begin{array}{c}\text { Bunke } \\
\text { ring }\end{array}$ & Dust & Dust & $\begin{array}{l}\text { Water } \\
\text { quality }\end{array}$ & $\begin{array}{c}\text { Relati } \\
\text { onship } \\
\text { with } \\
\text { local } \\
\text { comm } \\
\text { unity }\end{array}$ \\
\hline 9 & $\begin{array}{l}\text { Traffic } \\
\text { volume }\end{array}$ & $\begin{array}{c}\text { Port } \\
\text { develo } \\
\text { pment } \\
\text { (land } \\
\text { related } \\
\text { ) }\end{array}$ & $\begin{array}{c}\text { Port } \\
\text { develo } \\
\text { pment } \\
\text { (water } \\
\text { related } \\
\text { ) }\end{array}$ & $\begin{array}{c}\text { Port } \\
\text { develo } \\
\text { pment } \\
\text { (land } \\
\text { related } \\
\text { ) }\end{array}$ & Dust & $\begin{array}{l}\text { Ship } \\
\text { waste }\end{array}$ \\
\hline $\begin{array}{l}1 \\
0\end{array}$ & $\begin{array}{l}\text { Industr } \\
\text { ial } \\
\text { effluen } \\
t\end{array}$ & $\begin{array}{l}\text { Ship } \\
\text { discha } \\
\text { rge } \\
\text { (bilge) }\end{array}$ & $\begin{array}{c}\text { Port } \\
\text { develo } \\
\text { pment } \\
\text { (land } \\
\text { related } \\
\text { ) }\end{array}$ & $\begin{array}{l}\text { Water } \\
\text { quality }\end{array}$ & $\begin{array}{l}\text { Dredgi } \\
\text { ng: } \\
\text { operati } \\
\text { ons }\end{array}$ & $\begin{array}{c}\text { Climat } \\
\text { e } \\
\text { change }\end{array}$ \\
\hline
\end{tabular}

\section{MUNICIPALITY OF PERAMA}

The main environmental problems of the Municipality of Perama are:

1) Air and sea pollution (ex PCT, Psyttalia, traffic congestion, shipbuilding, shipyards, etc.)

2) Labor and technological accidents (Shipbuilding Zone, Oil Companies)

3) Noise pollution (traffic, Shipbuilding Zone, PCT)

4) Waste management (landfill transshipment station, Psyttalia)

5) The lack of development of the ecological potential of Mount Egaleo

6) The difficulty of joining the urban and social fabric of the city of the newly-abandoned areas (Ano Perama) that were degraded by the regime.

As we observe, most of the environmental problems presented by the Municipality of Perama are directly related to the port of Perama and its functions.[4]

- The Port of Perama city is consisted of the following:

- The Navy's facilities

- The marina at the end of Perama city

- $\quad$ The Ferry Boat Terminal - Perama city to Salamis island

- $\quad$ The Shipbuilding Zone
- The marina at Armos

- $\quad$ The Petroleum product installations

- The Piraeus Container Terminal (PCT)

Specifically, at the western end of the waterfront of Perama Municipality, behind the ferry boat line Perama city to Salamis island, there is a small cove, which is the beach of Perama and is surrounded by a small hill on which is the municipal swimming pool of the Municipality of Perama. At the edge of Perama beach there is a long pier used for recreation of residents of Perama (the outer side), car parking as well as a marina and repairs of small vessels (the inner side). The above place is the only place in which citizens have access to the sea as well as along the entire vehicle main transit route from Perama to Keratsini city, Perama's Shipyards are extended. After the Shipbuilding Zone of Perama, another small marina is being extended, in Armos location. After that, along the coastline and in a short distance from the houses of the residents of the Municipality of Perama, the Oil companies with the Petroleum product installations are located. The last part of the port of Municipality of Perama which extends almost parallel to the oil facilities are the Pireaus Container Terminal (PCT and OLP facilities) to N.Ikonio of Perama, which consists of three piers: I, II and III.

\section{QUESTIONAIRE}

During the period $16 / 7 / 2018$ to $30 / 7 / 2018$ the questionnaire was distributed to a sample of 50 people (permanent residents of Perama (42\%), employees in the city (54\%) and people who had no connection with the municipality $(4 \%))$ in order to investigate the prevailing view of how big the environmental pollution of the city is, and the extent they consider it is influenced by the port's operation in the city. The questionnaires were distributed in a printed form, however the data were being transferred to electronic files, so that they can be processed using statistical software. Specifically, we used the SPSS (Statistical Package for Social Science) and, with respect to data processing, the appropriate method was applied depending on the type of each variable. The sample was almost equal in both sexes (men: $44 \%$ and women: $56 \%$ ). The respondents were all adults, and covered the age range from 26 to 65 years. However, most of the questionnaires belonged to the 26-35 age group (42\%). In addition, most of the respondents $(60 \%)$ were married, with almost all the other unmarried (32\%), with only one widow. As regards their professional status, the most of them were public servants $(34 \%)$ and private employees $(46 \%)$, most of whom were either university graduates or holders of a postgraduate degree. The validity of the results was checked through the SPSS program and, in particular, the Alpha Crombach index. The audit was performed for all parametric queries, the results of which were used in our research - with the exception of the category of personal questions. For all the questions, the Alpha Crombach Validity Index was more than 0.7 which confirms the validity of our results.

From the correlation of the personal data of the respondents and how satisfied they are with the environmental characteristics of the city of Perama, using SPSS program, there is no correlation between these variables. However, we have come to the following observations:

Permanent residents and employees in the area are particularly in favor of their views on how satisfied they are with the environmental characteristics of the city, with the exception of the city's highway quality, in which employees are more 
satisfied than residents, and the management waste, in which employees are more dissatisfied from the resident population. Regarding the environmental characteristics of the city in relation to the respondents' age, we observe that in the sample the views converge, with the smaller age group of the sample (26-35) to be appeared slightly more satisfied than the other age groups. From the correlation of the opinion of the respondents on the environmental situation of Perama city regarding how much they think that the pollution of the city port contributes to environmental pollution, there is no correlation between these variables. However, most of the respondents believe that the environment is in poor condition but can be saved with a lot of effort. Finally, with regard to the responsibility for environmental pollution in the city of Perama, most of the responses were concentrated on the active industries in the area and on the operation of port facilities, and on the question of who they feel that is responsible for creating a healthy and safe environment, except the environmental organizations, all possible answers accounted for almost the same percentage of responses, while largest the responsibility of all was gathered by the government with 40 positive responses over 50 respondents.

\section{THE CASE STUDY OF PORT OF PERAMA CITY}

\subsection{Marine Pollution of the Perama City}

The measurements according to which we will draw conclusions come from Ph.D. thesis of Mr. Apostolos M. Moustakis entitled "Examination of marine pollution in the coastal zone from Piraeus to Perama" and concern two different time periods: The period 1997-2003 and the May of 2005.

The sampling areas are as follows:

- Germaniki Skala

- Port of Perama

\section{- $\quad$ Beach of Perama}

In order to draw conclusions, the content of marine samples in the following heavy metals (in decreasing order of toxicity) was examined: Copper $(\mathrm{Cu})$, Zinc $(\mathrm{Zn})$, Nickel $(\mathrm{Ni})$, Lead $(\mathrm{Pb})$, Chromium $(\mathrm{Cr})$ and Iron $(\mathrm{Fe})$. With the exception of the nickel which exhibits a significant drop in price and the chromium, which in particular in Germaniki Skala and Port of Perama area shows a strongly increasing trend, all other metals remain constant, having very small fluctuations either up or down. Analytically, lead and copper remain almost constant at the two different sampling times. The same thing happens with Zinc and Iron, metals mainly from work in the shipping industry. The valid Greek legislation was used to evaluate the results of these measurements. More specifically, the definition of the limits of heavy metal prices in marine waters was made on the basis of "PYS. 2/2001 (Government Gazette 15 / A / 2.2.2001) Determination of the guide and limit values for water quality from discharges of certain dangerous substances falling under List II of Council Directive 76/464 / EEC of 4 May 1976 "[5].

The analysis of the data resulted in the following conclusions:

Lead shows near-constant values throughout marine sampling, which is much higher than the limit set by Greek law $(20 \mu \mathrm{g} /$ $\left.\mathrm{m}^{3}\right)$. Chromium exhibits a strong upward trend, exceeding the limits of Greek legislation $\left(50 \mu \mathrm{g} / \mathrm{m}^{3}\right)$, indicating a possible intensification of shipbuilding repairs. Zinc ranges well below the limits of Greek legislation $\left(1000 \mu \mathrm{g} / \mathrm{m}^{3}\right)$, so it is not a problem for the environment. Copper ranges in the upper limits of Greek legislation $\left(50 \mu \mathrm{g} / \mathrm{m}^{3}\right)$, while iron, despite constant values over time, exceeds the $200 \mu \mathrm{g} / \mathrm{m}^{3}$ limit, which is expected to be the basic material in the shipping industry. Nickel, although declining, rates well above the statutory Greek limit of $100 \mu \mathrm{g} / \mathrm{m}^{3}$.

\subsection{Air Pollution of the Perama City}

The following diagram shows the particulate (PM10) measurements per month for the Perama area over a year, with two sampling points: the City Hall and the Philharmonic [3].

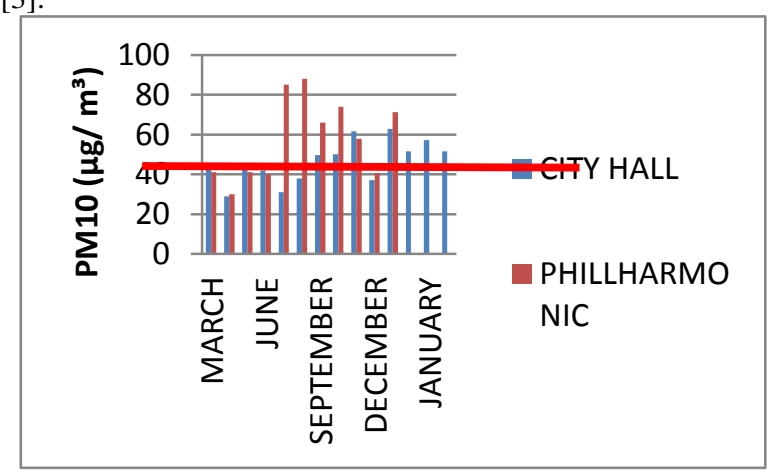

Figure 1: Average Conditions For Concentration Of Total Pm10 In Mg / $\mathrm{M}^{3}$

The red line indicates the limit of Greek legislation $(50 \mu \mathrm{g}$ $\mathrm{m}^{3}$ PM10 on a daily basis) which should not be exceeded more than 35 times per calendar year, while on an annual basis the limit is $40 \mu \mathrm{g} / \mathrm{m}^{3}$ PM10 to protect human health, according to the "PYS 34/2002 (Government Gazette 125 / A / 5.6.02) - Limit values and guidelines for the quality of the atmosphere in sulfur dioxide, nitrogen dioxide and oxides of nitrogen, particulate matter and lead "[6].

We note that in both measurement areas there are exceedances of the statutory limit, and that the annual average for the area exceeds the annual limit value since it is $51.1 \mu \mathrm{g} / \mathrm{m}^{3}>40 \mu \mathrm{g}$ $/ \mathrm{m}^{3}$. However, comparing the two measuring ranges shows that in the City Hall there is less concentration of PM10 then the Philarmonic region, which is closest to the Shipbuilding Zone and the port of Perama. In addition, the City Hall of Perama city is in a more open space, which is likely to favor the dilution of the measurement sample.

The chemical composition of the PM10 suspended particles of heavy metals in the two study areas (Town Hall and Philharmonic) was then studied in order to assess the extra burden of the existing marine pollution of the Perama area of these particles. On Philharmonic area we observe that none of the heavy metals has a linear correlation in its concentration, which implies an impermanence in the work done in the region. In more detail, the above measurements confirm the environmental impact of the operation of the shipyards in the town. For example, the metals zinc and chromium have many zeros samples, due to the periodicity of the work on ships. The measurements are similar for the "Town Hall" area. We observe that none of the above metals shows a linear correlation in the concentration, which indicates a temporary nature of the work done in the area, while the above measurements confirm the environmental burden of the operation of the Shipbuilding Zone in the city as well as the operation. 


\section{CONCLUSION}

We observe that Perama is a particularly aggravated region both in water and air pollution, with the concentrations of some heavy metals and suspended particles to be greater than the statutory limits.

More specifically, with regard to marine pollution, iron concentrations in the samples were particularly high, which is to be expected if one considers that it is the basic building material in shipping. Concentrations of copper are also high due to the shipbuilding zone and the port in general, due to the propellers' colors that are used as a toxic to algae and plankton. Chromium exhibits a strongly upward trend, exceeding the limits of the Greek legislation, revealing a possible intensification of the shiprepair work and although zinc concentrations are well below those that are set in Greek legislation, significant fluctuations appearing in concentrations due to the periodicity of work on the use of new antifouling paints. With respect to air pollution, in two sampling positions are observed fluctuations of the measurement values, the Hall region exhibit a lower concentration of suspended particles than the Philarmonic region, which is closest to the shipyards and port of Perama. This parallel variation implies that increased concentrations of PM10 in the Philarmonic region are due to the operation of the Shipbuilding Zone, possibly due to illegal sandblasting.

Finally, citizens who either live or work in the city are consistent with all the above, as they replied that they believe that the operation of the port facilities in the city affects the environmental pollution of the Municipality from a moderate to very much extend. At the same time, they said they expect the government, the local authorities and the industries operating in the region to take responsibility and take action to tackle the problem.

\section{ACKNOWLEDGMENTS}

All authors would like to thank the University of West Attica and specifically the Post Graduate Program of Studies (MSc) "New Technologies in Shipping and Transport", for the financial support provided to them to undertake this research project.

\section{REFERENCES}

[1] Ecoports. (N.d.). published in: https://www.ecoports.com $(01 / 02 / 2018)$

[2] Harry Geerlings, Bart Kuipers, Rob Zuidwijk (2017). Ports and Networks: Strategies, Operations and

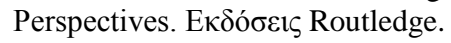

[3] Moustakis, A. M. (2005). Exploration of the sea pollution in the coastal zone from piraeus to the permanent. PhD Thesis, University of Piraeus, Piraeus.

[4] PERAMA: A greek - english edition of the city's history. (2005). Perama: Alexandros Publications.

[5] П.Y.ऽ. 2/2001 (ФЕК 15/A`/2.2.2001) Determination of the guide and limit values for water quality from discharges of certain dangerous substances falling within List II of Council Directive 76/464 / EEC of 4 May 1976 (in Greek).

[6] П.Y.ऽ. 34/2002 (ФЕК 125/A/5.6.02)- Limit values and guide values for air quality in sulfur dioxide, nitrogen dioxide and oxides of nitrogen, particulate matter and lead (in Greek). 